\title{
Oil to Biodiesel from Two Potential Sources - A 360 degree Comparative Study
}

S.Nandi ${ }^{1}$, R.Bhattacharyya ${ }^{2} \&$ S.Das ${ }^{3}$

${ }^{1}$ Head and Associate Professor, Department of Basic Science and Humanities, Narula Institute of Technology, Kolkata, India.

${ }^{2}$ Assistant Professor, Department of Basic Science and Humanities, Narula Institute of Technology, Kolkata, India.

${ }^{3}$ Research Scholar, Department of Chemical Engineering, University of Calcutta, Kolkata, India.

DOI: 10.38177/ajast.2020.4313

Jatropha curcas oil (JCO) and karanja oil have been identified for the comparative study of production of renewable energy sources i.e. biodiesel as well as physico-chemical properties of biodiesel for its potentiality. Enzyme Novozyme 435 (Candida antarctica) is used as biocatalyst ( $8 \%$ ) for the conversion in both the cases with 5:1 molar ratio of alcohol to oil for 8 hours with mixing intensity of $600 \mathrm{rpm}$ at $55^{\circ} \mathrm{C}$. JCO shows higher conversion efficiency at these parameters than karanja oil. Biodiesels obtained from JCO and karanja oil are analysed based on physico-chemical properties like specific gravity, kinematic viscosity, density, calorific value, cetane number, flash point, cloud point and acid number. With regard to specific gravity, kinematic viscosity, density, calorific value and cetane number, the JCO biodiesel shows higher values than karanja biodiesel whereas flash point and cloud point of karanja biodiesel are higher than JCO biodiesel. With respect to the compositional analysis, JCO biodiesel contains $95.67 \%$ methyl ester but karanja biodiesel contains $92.57 \%$ methyl ester. Apart from this, triglycerides (TG), diglycerides (DG) and monoglycerides (MG) content of JCO and karanja oil biodiesel are $1.68 \%, 1.08 \%, 2.68 \%$ and $1.89 \%, 2.75 \%$ and $3.69 \%$ respectively.

Keywords: Candida Antarctica, Cetane number, Jatropha curcas oil, Karanja oil, Methyl ester.

\section{Introduction}

Production of biodiesel (BD) as alternative renewable energy sources are supposed to be the most challenging job in today's world [1-5]. Different raw materials have been identified for the production of biodiesel through transesterification and esterification reactions. Different catalysts are also used for this purpose using different parameters [6]. Chemical catalysts as well as biocatalysts are utilized for the smooth conduction of the processes. JCO, karanja oil, mahua oil, neem oil, castor oil, rubber seed oil, different fatty acid distillates are mainly used as nontraditional source for the production of biodiesel apart from edible oils. Li et al studied the production of biodiesel from Pistacia chinensisbge seed oil in the presence of biocatalyst [7]. Kawakami et al analysed the batch and continuous biodiesel production using JCO and methanol by applying Burkholderia cepacia lipase [8]. Present author also studied production of biodiesel from JCO with recycling of enzyme [9], by using chemical and enzymatic catalyst [10], from canola oil deodorizer distillate [11] and also from waste cooking oil [12]. Cucurbita Pepo L. Seed Oil was also used by Ogbu and Ajiwe [13] for kinetic studies to produce biodiesel. Crude neem oil, karanja oil and recycled cooking oil were also studied by several researchers for biodiesel production and its characterization [14-17].

Very little information has been made regarding the comparative studies for the production of biodiesel simultaneously from two different raw materials maintaining same reaction parameters. Biodiesel production from Pongamia pinnata, Calophyllum inophyllum, and waste cooking oil and comparative engine performance has been studied by Afzal et. al [18] and obtained good results for blended fuels. Satyanarayana and Muraleedharan made a comparative study for biodiesel production from Rubber Seed Oil, Coconut Oil, and Palm Oil Including Thermogravimetric Analysis and showed that coconut oil biodiesel is better fuel than other two biodiesels [19]. A comparative ultrasound biodiesel production has been studied by Shinde and Kaliaguine [20] using different homogenous catalysts. In the present research investigation, a comparative studies has been made for production of 
biodiesel from JCO and karanja oil simultaneously regarding same production process and physico-chemical properties of both the oils and biodiesels with respect to diesel fuel and biodiesel standard. A compositional analysis has also been done for both the biodiesels. This new comparative results may be helpful for future researches for alternative fuel domain.

\section{Experimental}

\subsection{Materials}

The The JCO and karanja oil (Pongamia pinnata L.) used in this study were provided by M/s. A.S. Oil Mills, Burdwan, West Bengal, India. The enzyme used in the following studies was Novozyme 435 (Candida antarctica) immobilized lipase which was a kind gift of Novozyme South Asia Pvt. Ltd. Bangalore, India. The chemicals used in this work methanol and hexane were purchased from S.D. Fine Chemicals (Mumbai, India). Except otherwise specified all other chemicals used were A.R. Grade.

\subsection{Optimization of Reaction}

For transesterification reaction of JCO and Karanja oil with alcohol in the presence of enzyme, initially $250 \mathrm{~mL}$ of crude oil was taken in an Erlenmeyer flask separately and heated up to $80^{\circ} \mathrm{C}$ to drive off moisture by continuous stirring for about $1 \mathrm{~h}$. After that, transesterification reaction was carried out by stepwise addition of alcohol in an appropriate proportion using solvent hexane fitted with a water condenser and stirred by a magnetic stirrer at a specified temperature for 8 hours maintaining other reaction conditions. To the reaction mixture, immobilized enzyme Novozyme 435 was added in definite proportion (w/w). Stepwise addition of methanol was allowed to minimize the deactivation of enzyme.

\subsection{Product Analysis}

During the reaction, continuous sampling and analysis were done by withdrawing the sample in to a capped vial and removing enzyme through centrifugation. The progress of reaction or production of biodiesel was monitored by thin layer chromatographic (TLC) method and the typical yield of each reaction product was determined separately by column chromatography. TLC was done by spotting the lipid mixture on a silica-gel G plate $(0.2 \mathrm{~mm}$ thick) using hexane-diethyl ether-acetic acid (90:10:1) as a developing solvent. The lipid spots were identified by iodine absorption with TG, DG, MG and BD as standard. The composition of different esters using was determined by column chromatography using silicic acid as an adsorbent and $160 \mathrm{~mL}$ of hexane-diethyl ether: 99:1 as eluting solvent. After completion of reaction, the enzyme was washed with hexane, dried and reused for the next experiment. Biodiesel characterization was done according to the American Standard Testing Method (ASTM). Values are reported as mean \pm s.d., where $n=3$ ( $n=$ no of observations).

\section{Results and Discussions}

\subsection{Characteristics of JCO and Karanja Oil}

Table 1 shows the fatty acid composition and characteristics of JCO and karanja oil used for the preparation of BD. It has been observed from the Table that JCO and karanja oil contain almost equal amounts of palmitic acid but 
stearic acid content is slightly higher in case of JCO. karanja oil contains much higher amount of oleic acid than JCO but linoleic acid content is much higher in case of JCO than karanja oil. Karanja oil contains long chain fatty acids like eicosanoic acid, docosanoic acid and tetracosanoic acid which is unlike JCO.

Regarding physico-chemical characteristics, karanja oil has higher flash point and kinematic viscosity but calorific value, cetane number, cloud point iodine value and acid value of JCO is higher than karanja oil. Other characteristics of both the oils are comparable.

Table 1: Physicochemical properties of JCO and karanja oil

\begin{tabular}{|c|c|c|c|c|c|}
\hline Fatty acids & JCO & Karanja oil & Characteristics & JCO & Karanja oil \\
\hline Palmitic acid & $11.73 \pm 0.125$ & $11.11 \pm 0.103$ & $\begin{array}{c}\text { Acid value (mg } \\
\mathrm{KOH} / \mathrm{gm})\end{array}$ & $18.86 \pm .127$ & $3.17 \pm 0.004$ \\
\hline Stearic acid & $9.37 \pm 0.041$ & $7.43 \pm 0.072$ & Flash point $\left({ }^{0} \mathrm{C}\right)$ & $190 \pm 1.275$ & $216 \pm 1.110$ \\
\hline Oleic acid & $39.64 \pm 0.179$ & $51.74 \pm 0.291$ & Cloud point $\left({ }^{0} \mathrm{C}\right)$ & $4.8 \pm 0.652$ & $3.3 \pm 0.004$ \\
\hline Linoleic acid & $37.96 \pm 0.148$ & $15.23 \pm 0.106$ & Pour point $\left({ }^{0} \mathrm{C}\right)$ & $-1 \pm 0.007$ & $3.7 \pm 0.005$ \\
\hline Eicosanoic acid & & $1.27 \pm 0.006$ & Density $(\mathrm{gm} / \mathrm{cc})$ & $0.926 \pm 0.042$ & $0.937 \pm 0.036$ \\
\hline Docosanoic acid & & $4.81 \pm 0.011$ & $\begin{array}{l}\text { Kinematic Viscosity } \\
\left(\mathrm{mm}^{2} / \mathrm{s}\right)\left(40^{0} \mathrm{C}\right)\end{array}$ & $28.35 \pm 1.074$ & $37.64 \pm 0.037$ \\
\hline \multirow[t]{6}{*}{ Tetracosanoic acid } & & $1.01 \pm 0.001$ & Iodine value & $109 \pm 1.871$ & $93 \pm 1.034$ \\
\hline & & & $\begin{array}{c}\text { Unsaponifiable } \\
\text { matter }\end{array}$ & $3.8 \pm 0.038$ & $2.9 \pm 0.019$ \\
\hline & & & $\begin{array}{c}\text { Carbon residue } \\
\text { (w/w \%) }\end{array}$ & $1.77 \pm 0.042$ & $1.49 \pm 0.001$ \\
\hline & & & Specific gravity & $0.932 \pm 0.024$ & $0.939 \pm 0.007$ \\
\hline & & & $\begin{array}{l}\text { Calorific value } \\
(\mathrm{Kcal} / \mathrm{Kg})\end{array}$ & $9432 \pm 1.274$ & $8725 \pm 1.678$ \\
\hline & & & Cetane number & $54 \pm 0.651$ & $48 \pm 0.357$ \\
\hline
\end{tabular}

\subsection{Comparative Analysis of Molar Ratio of Alcohol to Oil for Biodiesel Production}

A comparative study has been made for alcohol to oil ratio for maximization of biodiesel production for both the oils. Transesterification reaction for JCO and karanja oil with methanol has been arranged separately at $55^{\circ} \mathrm{C}$ for 8 hours with mixing intensity $600 \mathrm{rpm}$ in the presence of $8 \%$ enzyme which shows that conversion of biodiesel is higher for JCO than karanja oil as shown in Fig. 1. It has also been observed from the figure that in all molar ratios, 
JCO contributes higher amount of biodiesel production than karanja oil. Enhancing the amount of alcohol for both the cases increases the percentage conversion but for JCO it is higher. At 2:1 molar ratio of alcohol: oil, JCO converts 5.69\% higher than karanja oil. Similarly, at 3:1 and 4:1 molar ratio, conversion of biodiesel are $6.61 \%$ and $5.89 \%$ higher for JCO than karanja oil respectively. But 5:1 molar ratio of alcohol: JCO is the optimum ratio for JCO for conversion while karanja (4.1\% less conversion than JCO) could not contribute optimum conversion at this ratio. Even 6:1 molar ratio of alcohol: karanja has not been identified as optimum ratio for it. At this ratio, it reaches $1.2 \%$ less conversion than optimum level. It would reach beyond that $(6.43: 1)$ for its optimum conversion as observed from Fig.1.

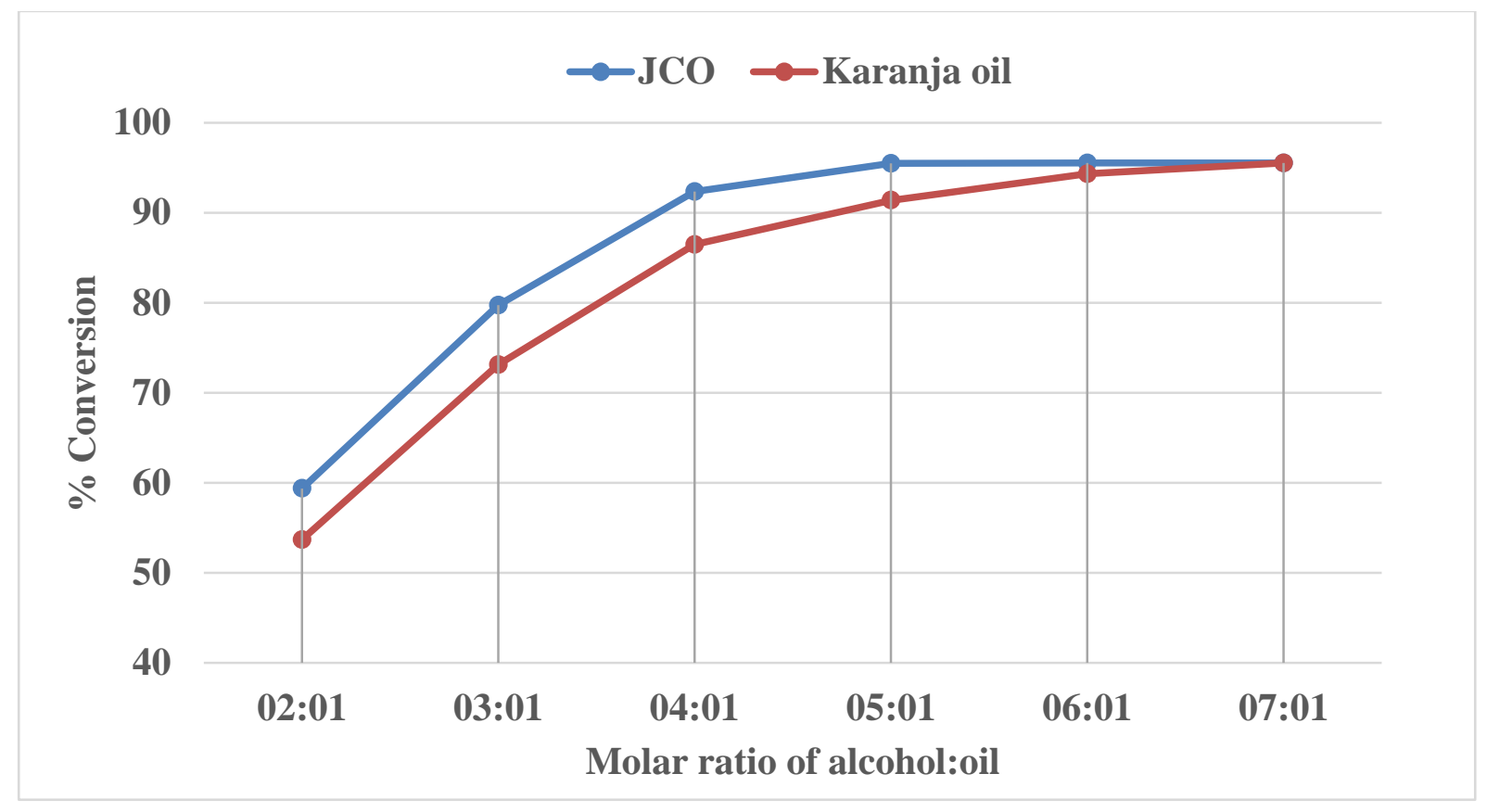

Fig.1: Comparative Analysis of Molar Ratio of MEOH to Oils

[TEMPERATURE: $55^{\circ} \mathrm{C}$, TIME: 8 HRS, MIXING INTENSITY: 600 RPM AND ENZYME: 8\% (W/W)]

\subsection{Comparative Analysis of Temperature for Biodiesel Production}

Percent conversion of any product depends on activation energy of the reaction and activation energy is governed by the temperature of the reaction. A comparison of temperature has been studied for biodiesel production from JCO and karanja oil separately at 5:1 molar ratio of alcohol to oil for 8 hours with mixing intensity $600 \mathrm{rpm}$ in the presence of $8 \%$ enzyme shown in Fig.2.

It is revealed from the figure that increasing temperature increases the conversion of biodiesel for both the cases up to a certain temperature but conversion is higher in case of JCO than karanja oil at any particular temperature. At $40^{\circ} \mathrm{C}$, JCO converts $7.93 \%$ more than karanja oil. Similarly, at $45^{\circ} \mathrm{C}$ and $50^{\circ} \mathrm{C}$, the conversions are $9.85 \%$ and $15.69 \%$ higher in case of JCO than karanja oil. At $55^{\circ} \mathrm{C}$, maximum conversion has been achieved for JCO but karanja oil converts $18.25 \%$ less than the former. For the latter, it requires $60^{\circ} \mathrm{C}$ for optimum conversion though at this temperature, no development has been observed for JCO. After that increasing temperature up to $65^{\circ} \mathrm{C}$, conversion decreases for both the cases. This may be due to the inactivation of enzyme because beyond a certain 
temperature, each enzyme becomes deactivated. Higher temperature also volatilize methanol which hampers the proper ratio of methanol to oil.

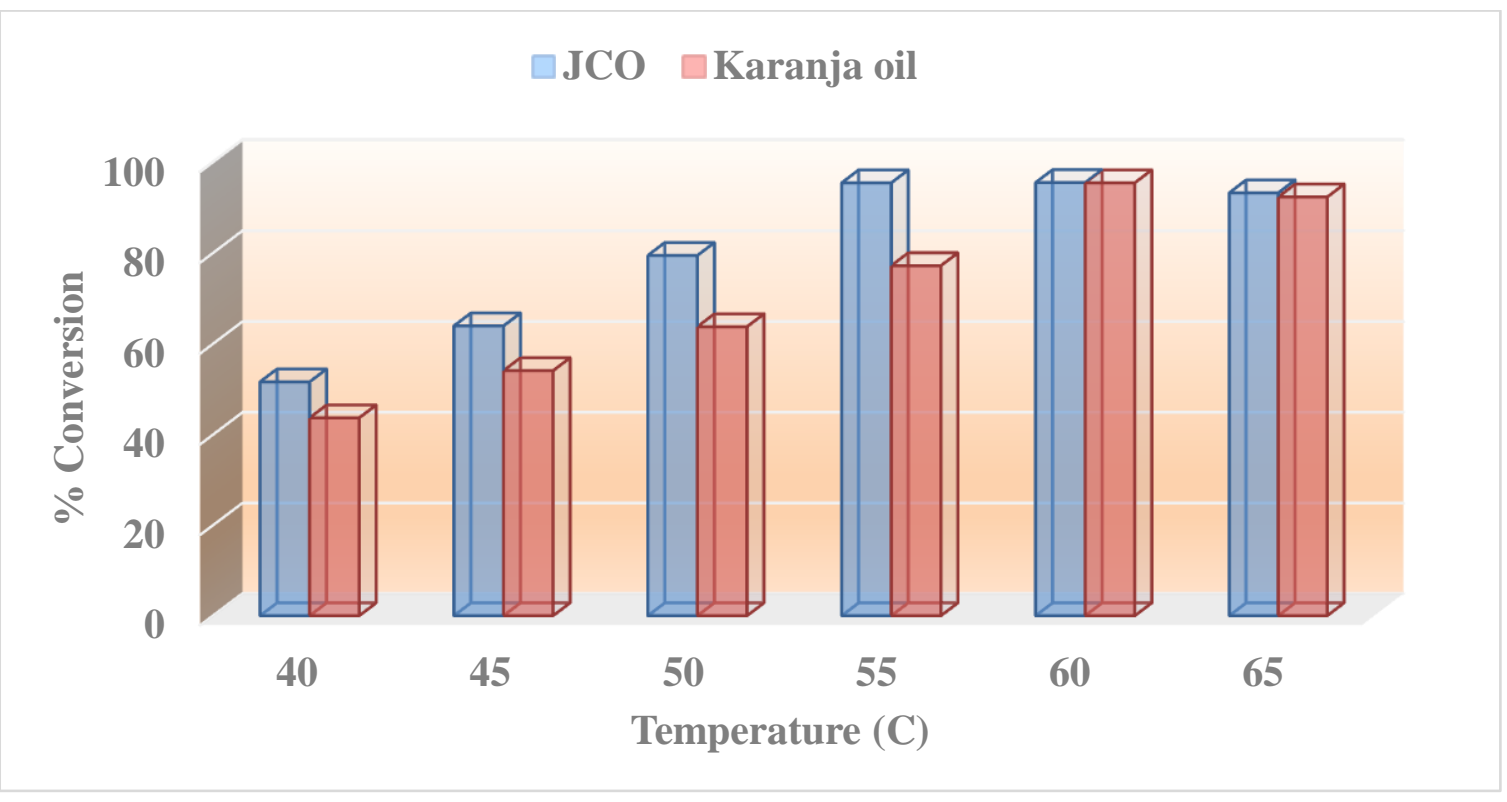

Fig.2: Comparative Analysis of Temperature for Biodiesel Production

[MOLAR RATIO: 5:1, TIME: 8 HRS, MIXING INTENSITY: 600 RPM AND ENZYME: 8\%(W/W)]

\subsection{Comparative Analysis of Catalyst Concentration for Biodiesel Production}

Effect of concentration of enzyme for the production of biodiesel from JCO and karanja oil was investigated separately at 5:1 molar ratio of alcohol to oil for 8 hours with mixing intensity $600 \mathrm{rpm}$ at $55^{\circ} \mathrm{C}$ as shown in Fig. 3 .

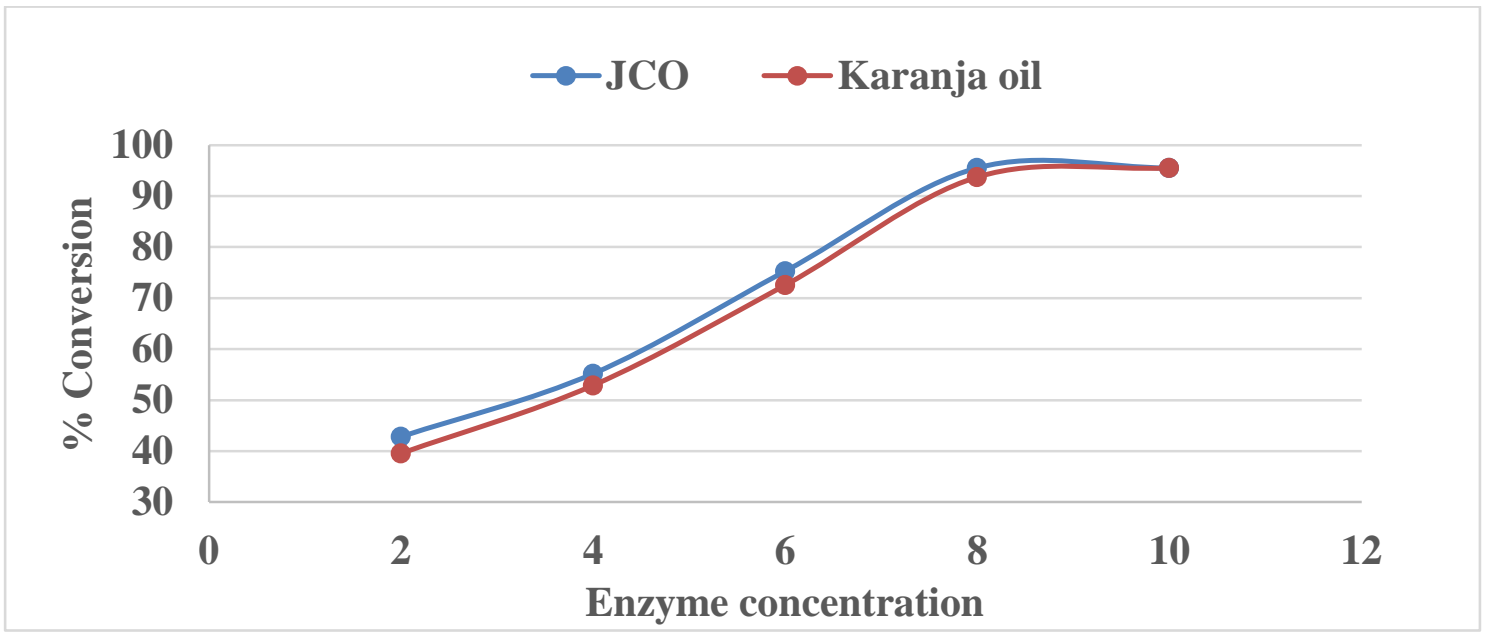

Fig.3: Comparative Analysis of Enzyme Concentration for Biodiesel Production

[MOLAR RATIO: 5:1, TIME: 8 HRS, MIXING INTENSITY: 600 RPM AND TEMPERATURE: 55ㄷ]

It has been observed from the figure that difference in effect for the concentration of enzyme on both the oils for biodiesel production is fewer. Increasing concentration of enzyme for the both the cases enhances the rate of conversion of product. In the presence of $2 \%$ enzyme, conversion of biodiesel from JCO is $3.27 \%$ higher than 
karanja oil. For $4 \%$ and 6\% enzyme concentration, biodiesel production is $2.29 \%$ and $2.73 \%$ higher respectively in case of JCO. But at $8 \%$ concentration of enzyme, JCO contributes maximum conversion while it is $1.79 \%$ less for karanja oil. For karanja oil, maximum conversion has been achieved at nearly $9 \%$ concentration of enzyme. So JCO gives faster conversion than karanja oil and so it is more beneficial considering biodiesel production. Higher concentration of enzyme (10\% or higher) did not produce higher amount of biodiesel as obtained from the figure. This may be due to the fact that availability of active site of enzymes are responsible for substrate conversion rate. Due to presence of higher amount of enzyme, all active sites would not be available to the substrates due to enzyme aggregation which actually reduces the conversion rate.

\subsection{Comparative Analysis of Mixing Intensity for Biodiesel Production}

Mixing intensity or stirring of the reaction in a definite rpm helps the substrates to reach near the active sites of the enzyme which ultimately contributes optimum production. In our study, mixing intensity has been compared for production of biodiesel from JCO and karanja oil separately through transesterification reaction with alcohol at 5:1 molar ratio of alcohol to oil for 8 hours at $55^{\circ} \mathrm{C}$ by varying stirring from $200-700 \mathrm{ppm}$ as shown in Fig. 4. It has been observed from Fig. 4 that at $200 \mathrm{rpm}$, the conversion of biodiesel from JCO is $4.3 \%$ higher than karanja oil. Similarly, at 300, 400 and $500 \mathrm{rpm}$, the conversion is $4.7 \%, 2.37 \%$ and $2.49 \%$ higher in case of JCO respectively. However, the optimum conversion from JCO and methanol has been achieved at $600 \mathrm{rpm}$ while at this rpm, karanja oil converts $2.91 \%$ less than JCO. Karanja oil achieved optimum conversion at 700 rpm as evidenced from Fig. 4. So, mixing intensity plays an important role for conversion of biodiesel from substrates. Moreover, increasing the mixing intensity did not enhance the conversion rate after optimum level as observed from figure. This may be due to the poor contact time between active sites of enzymes and substrates.

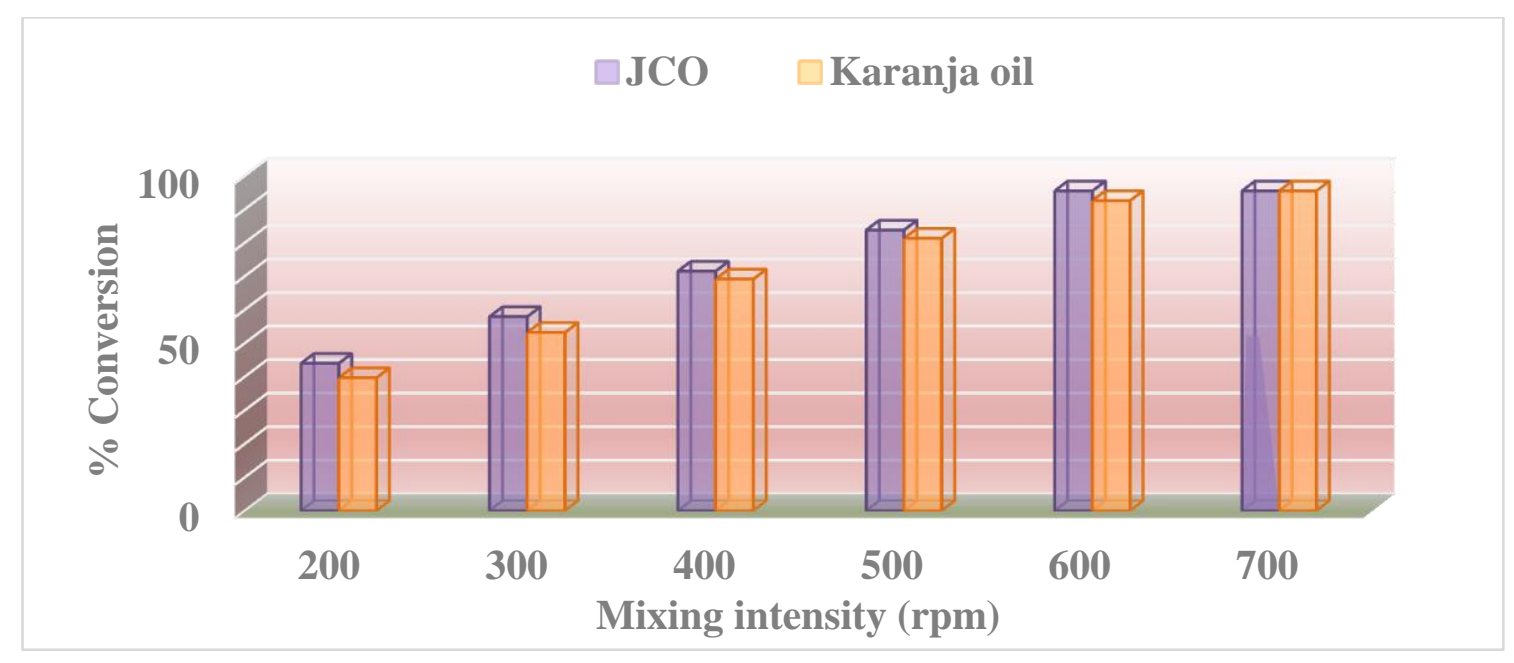

Fig.4: Comparative Analysis of Mixing Intensity for Biodiesel Production

[MOLAR RATIO: 5:1, TIME: 8 HRS, ENZYME: 8\% (W/W) AND TEMPERATURE: $55^{\circ} \mathrm{C}$ ]

\subsection{Compositional Analysis of Biodiesel from JCO and Karanja Oil}

The analysis of composition of biodiesel prepared from JCO and karanja oil have been done as shown in Fig. 5. It has been observed from the figure that biodiesel obtained from JCO contained higher amount of methyl esters 
(biodiesel - BD) (95.67\%) than biodiesel obtained from karanja oil (92.57\%) maintaining same reaction conditions. The amount of TG, DG and MG are also in higher percentage in karanja oil than JCO due to slightly lower conversion rate of oil to biodiesel in karanja oil. So applying identical reaction conditions for the conversion of biodiesel from JCO and karanja oil, the efficiency of JCO is higher than that of karanja oil as observed from the experimental studies.

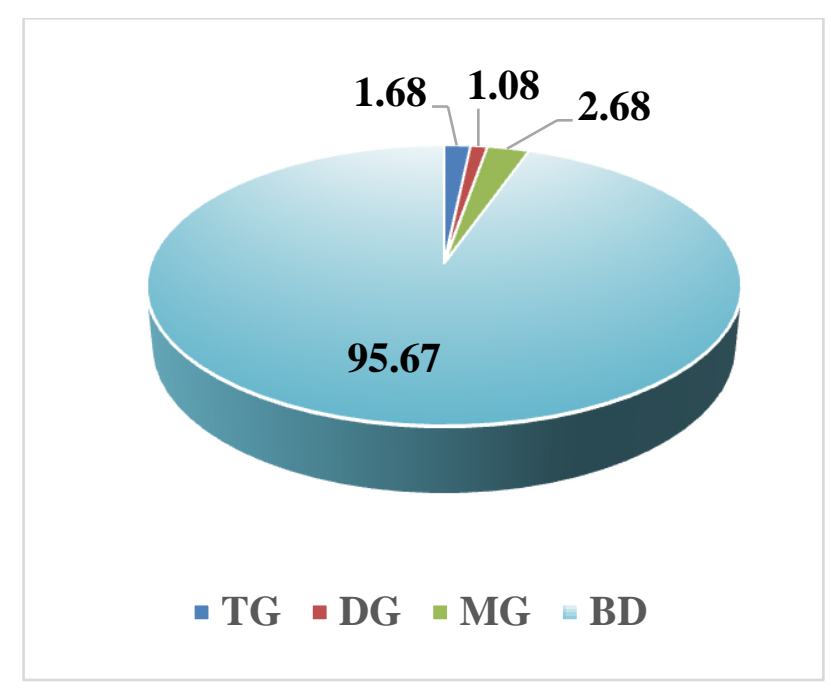

(a)

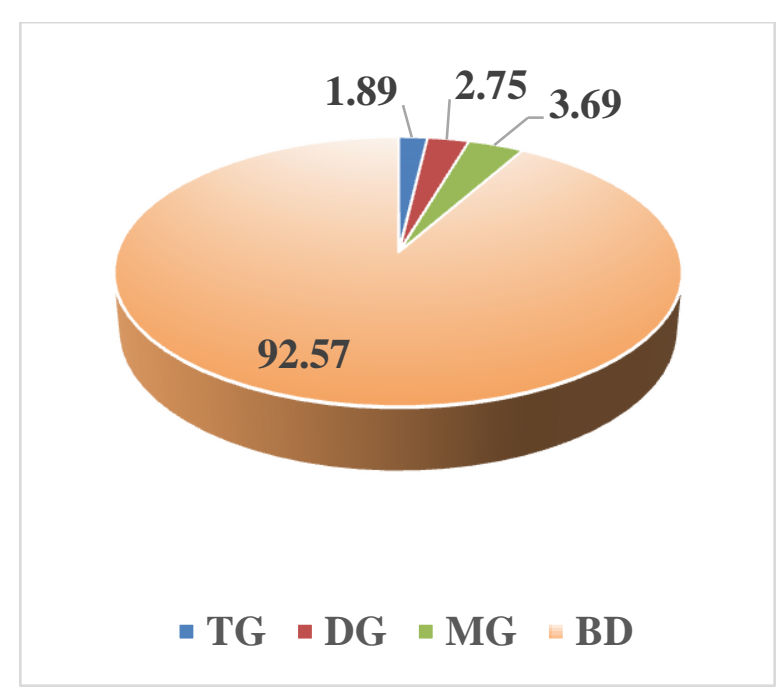

(b)

Fig.5: Compositional Analysis of Biodiesel from JCO (a) And Karanja Oil (b)

\subsection{Physico-Chemical Analysis of Biodiesel from JCO and Karanja Oil}

The characteristics of biodiesel obtained from JCO and karanja oil were analyzed and compared according to the ASTM standard as shown in Table 2. It has been observed from the table that both the products obtained from JCO and karanja oil are almost in conformity with the biodiesel standard. With regard to the characteristics of specific gravity, kinematic viscosity, density, calorific value and cetane number, the JCO biodiesel shows higher values than karanja biodiesel. But flash point and cloud point of karanja biodiesel are higher than JCO biodiesel. With regard to diesel fuel, kinematic viscosity is higher for both the biodiesels but calorific value of diesel fuel is higher than both the biodiesel prepared from JCO and karanja oil.

Table 2: Physico-chemical properties of biodiesel from JCO and karanja oil

\begin{tabular}{|l|c|c|c|c|c|}
\hline \multicolumn{1}{|c|}{ Properties } & JCO biodiesel & $\begin{array}{c}\text { Karanja } \\
\text { biodiesel }\end{array}$ & $\begin{array}{c}\text { Biodiesel } \\
\text { standard }\end{array}$ & Diesel fuel & Test method \\
\hline Specific gravity $\left(15^{0} \mathrm{C}\right)$ & $0.87 \pm 0.003$ & $0.859 \pm 0.007$ & $0.881-0.90$ & $0.82-0.95$ & ASTMD 6751-02 \\
\hline $\begin{array}{l}\text { Kin.viscosity }\left(\mathrm{mm}^{2} / \mathrm{s}\right) \\
\left(40^{\circ} \mathrm{C}\right)\end{array}$ & $5.13 \pm 0.012$ & $4.89 \pm 0.021$ & $1.96-6.0$ & $1.3-4.1$ & ASTMD 445 \\
\hline Density $(\mathrm{gm} / \mathrm{cc})$ & $0.882 \pm 0.112$ & $0.857 \pm 0.008$ & $0.865-0.90$ & $0.82-0.86$ & ASTMD 4052-96 \\
\hline
\end{tabular}


Volume 4, Issue 3, Pages 91-99, July-September 2020

\begin{tabular}{|l|c|c|c|c|l|}
\hline Calorific value $(\mathrm{MJ} / \mathrm{Kg})$ & $39.35 \pm 0.214$ & $36.52 \pm 0.311$ & $33-40$ & 45 & ASTM 6751 \\
\hline Flash point $\left({ }^{0} \mathrm{C}\right)$ & $153 \pm 0.453$ & $189 \pm 0.586$ & $>120$ & $60-80$ & ASTMD 93 \\
\hline Cloud point $\left({ }^{0} \mathrm{C}\right)$ & $5.3 \pm 0.054$ & $5.8 \pm 0.041$ & 5 & ----- & ASTMD 2500 \\
\hline Cetane number & $54 \pm 0.183$ & $45 \pm 0.125$ & 40 min & 50 & ASTMD 6751 \\
\hline Acid number & 0.32 & 0.29 & 0.5 max & --- & ASTMD 664 01 \\
\hline
\end{tabular}

\section{Conclusion}

Comparative studies of biodiesel prepared from jatropha curcas oil and karanja oil show that jatropha curcas oil converts faster rate than karanja oil maintaining identical reaction parameters though both are potential raw materials for alternative energy sources. The physico-chemical properties have been analyzed for both the biodiesels from two sources and in that case, both show good conformity with biodiesel standard and diesel fuel though JCO indicates higher calorific value than karanja oil. Compositional studies also showed higher methyl ester conversion in case of jatropha curcas oil. Based on the experimental study and observation, it has been predicted that both the oils may be recognized as potential cradles for the alternative energy sources which helps to mitigate the inadequacy of non-renewable energy sources in the near future.

\section{References}

1) S.N. Gebremariam and J M Marchetti, Economics of biodiesel production: review, Energy Convers. Manag., 168, 74-78, 2018.

2) K. Dutta, A. Daverey and J.G. Lin, Evolution retrospective for alternative fuels: first to fourth generation Renew Energy, 69, 114-122, 2014.

3) Y. Yan, X. Li, G. Wang, X. Gui, et al, Biotechnological preparation of biodiesel and its high - valued derivatives: a review, Appl. Energy, 113, 1614-1631, 2014.

4) J. Janaun, N. Ellis, Perspectives on biodiesel as a sustainable fuel, Renew. Sustain. Energy Rev., 14 (4), 1312-1320, 2010.

5) V.B. Veljkovic, I.B. Bankovicllic, O.S. Stamenkovic, Purification of crude biodiesel obtained by, heterogeneously- catalyzed transesterification, Renew. Sustain. Energy Rev., 49, 500-516, 2015.

6) S. Chozhavendhan, M.V. P. Singh, B. Fransila, R. P. Kumar and G. K. Devi, A review on influencing parameters of biodiesel production and purification processes, Current Research in Green and Sustainable Chemistry, Volumes 1-2, 1-6, February-April 2020.

7) X. Li, X. Y. He, Z. L. Li, Y. D. Wang, C. Y. Wang, H. Shi and F. Wang, Enzymatic production of biodiesel from Pistacia chinensisbge seed oil using immobilized lipase, Fuel, 92, 89-93, 2012.

8) K. Kawakami, Y. Oda, and R. Takahashi, Application of a Burkholderia cepacia lipase immobilized silica monolith to batch and continuous biodiesel production with a stoichiometric mixture of methanol and crude Jatropha oil, Biotechnology for Biofuels, 4 (42), 1-11, 2011. 
9) S. Nandi and R. Bhattacharyya, Production of biodiesel from Jatropha Curcas oil with recycling of enzyme, International Journal on Applications in Civil and Enviornmental Engineering, 1 (1), 1-5, 2015.

10) S. Nandi and R. Bhattacharyya, Biodiesel from Jatropha Curcas oil: A comparative study between chemical and biocatalytic transesterification, Research Journal of recent Sciences, 4(ISC-2014), 44-50, 2015.

11) S. Nandi, R. Bhattacharyya and G. Misra, Investigation of biodiesel from Canola oil deodorizer distillate using dual biocatalyst, Asian Journal of Applied Science and Technology, 4 (1), 131-138, January-March 2020.

12) S. Nandi, R. Bhattacharyya, D. Marik, T. K. Ghosh, Utilisation of Waste Cooking Oil as Biodiesel through Bioprocess Technology, International Journal for Research in Applied Science \& Engineering Technology, 8 (IV), 133-137, Apr 2020.

13) I.M. Ogbu and V. I. E. Ajiwe, Biodiesel Production via Esterification of Free Fatty Acids from Cucurbita Pepo L. Seed Oil: Kinetic Studies, International Journal of Science and Technology, 2(8), 616-621, 2013. 14) E. F. Aransiola, E. Betiku, D. I. O. Ikhuomoregbe and T. V. Ojumu, Production of biodiesel from crude neem oil feedstock and its emissions from internal combustion engines, African Journal of Biotechnology, 11 (22), 6178-6186, 2012.

15) F. Ouanji, M. Kacimi, M. Ziyad et al., Production of biodiesel at small-scale (10 L) for local power generation, Int. J. Hydrogen Energ., 42, 8914-8921, 2016.

16) R. K. A. Mookan, M. Sundaresan, P. Velan, Biodiesel production from pongamia pinnata oil using synthesized iron nanocatalyst, Int. J. Chem Tech Res., 6, 4511-4516, 2014.

17) K. Tahvildari, Y. N. Anaraki, R. Fazaeli et al., The study of $\mathrm{CaO}$ and $\mathrm{MgO}$ heterogenic nano-catalyst coupling on transesterification reaction efficacy in the production of biodiesel from recycled cooking oil, J. Environ Health Sci. Eng. 13, 73-81, 2015.

18) A. Afzal, M. Kareemullah and A. Razak,, Production of biodiesel from various sources and comparative engine perfor-mance studies by using different biodiesel blends, Journal of Engineering Research 6(4),1-21, 2019.

19) M. Satyanarayana and C. Muraleedharan, Comparative studies of biodiesel production from rubber seed oil, Coconut oil and Palm oil including Thermogravimetric Analysis, Energy sources, Part A: Recovery, Utilization and Environmental Effects, 33 (10), 925-937, 2011.

20) K. Shinde and S. Kaliaguine, A comparative study of ultrasound biodiesel production using different homogeneous catalysts, Chem Engineering, 3, 18, 2019. 